\title{
The Effect of Internal and External Factors on the Business Success of Agri-based Exporting Small and Medium Scale Enterprises in Thanh Hoa Province, Vietnam
}

\author{
Nguyen Thi Loan* \\ Faculty of Economic and Business Administration, Hong Duc University, Vietnam \\ *Corresponding author: nguyenthiloankt2@hdu.edu.vn
}

\begin{abstract}
The purposes of the research are to determine the main factors affecting the business success of agri-based exporting firms in Thanh Hoa Province. To achieve these research objectives, quantitative and qualitative method were used concurrently. 275 questionnaire survey was sent out, but only 180 respondents replied suitably for the quantitative analysis through SPSS 20.0 software. Cronbach's Alpha, EFA, and regression are taken to confirm the research result further. The research finding shows that external factors have much more affecting than others internal one on the business success of exporting SMEs, in which external factors have much effect on the Business Success of Agri-based Exporting Small and Medium-Sized Enterprises in Thanh Hoa Province than internal factors.
\end{abstract}

Keywords: factor, affecting, business success, agri-based exporting, SMEs

Cite This Article: Nguyen Thi Loan, "The Effect of Internal and External Factors on the Business Success of Agri-based Exporting Small and Medium Scale Enterprises in Thanh Hoa Province, Vietnam." Journal of Finance and Economics, vol. 6, no. 3 (2018): 87-95. doi: 10.12691/jfe-6-3-2.

\section{Introduction}

Strong export performance is usually known as one of the critical factors in driving a country's economic growth [1] since exports can improve a firm's production efficiency to overcome higher trade barriers and address different market tastes in competitive international markets. Agricultural product exports are considered to be the critical export sector of Vietnam, contributing $25-30 \%$ of gross domestic products [2] and $17-20 \%$ total export value of the country [3]. From a country facing the food shortage, Vietnam has emerged as an exporter of agricultural products and, in particular, we have become one of the 15 major exporters of agriculture products in the world with 30 billion USD per year over the last five years 2011-2015. Exporting firms, which directly introduce agricultural products introduced to the world, play a vital role in these successes of export activities of agricultural products. In Thanh Hoa, localities have great potential for agricultural development, but the value of export products is not commensurate with their potential and strengths. The reason is that there is no suitable direction to crop development, lack of international trade promotion activities, and lack of strong enough enterprises of participating genuinely in the global of the agricultural export market. With the desire to find out solutions to promote the development of agricultural export enterprises, contributing to increasing the output and export value, the author has studied the factors affecting the business success of agri based exporting enterprises in Thanh Hoa province, Vietnam.

\section{Overview of Small and Medium Scale Enterprises (SMEs)}

Because of the critical contributions, Small and Medium Enterprises (SMEs) always received particular attention from the leaders and the local authorities [4]. According to statistics from 132 countries around the world, many classifications of different enterprises for developed countries, they are based on the size of capital, revenue, and profitability, for developing nations based on the division of labor, some countries based on the contribution budget year [5]. Specifically, in the world, there are about $1 / 3$ of enterprises identified small and medium with a number of employees that is less than 250 people.

Typical characteristics of SMEs are difficult to access capital, market access and also vulnerable when leaving the market because of the barrier of large enterprises and binding economic policy [6].

In Vietnam, SMEs are classified based on two criteria; they are capital and labor. Under Decree No. 90/2001/ND-CP defines small and medium enterprises as "production base of independent businesses, with registered business under current legislation, has registered capital of no more 
than 10 billion copper or the average annual labor not exceeding 300 people. Article 03, decree 56/2009 regulates "Small and Medium Enterprises are enterprises which filed for business registration under current laws and divided into three levels including microenterprises, small enterprises and medium enterprises relying on criteria of annual total capital and labor (appreciate criterion of total capital resource relying on data in yearly statement of financial position of enterprises), specifically.

SME plays a vital role in the development of the national economy, which is a catalyst for the growth of the economy [6]. SMEs generate more than $60 \%$ of the labor force annually, contributing nearly $50 \%$ of the country's GDP, supplying $55 \%$ of the goods and services to the market. For developed countries the proportion of SMEs is $80-95 \%$, meanwhile the developing countries like Vietnam, SMEs account for 97-98\% [7]. SME is also the main force for star-up revolution, job creation and boosting the local economic development.

\section{Overview of Agri Based Exporting SMEs in Thanh Hoa Province, Vietnam}

The total export value in 2016 was estimated at $1,719.189$ million USD, equal to $160 \%$ of the plan, up $13.4 \%$ over the same period. In which formal export was estimated at $1,535.599$ million USD, equal to $139.4 \%$ of the plan, up $26.7 \%$ over the same period; informal export and enterprises outside the province were estimated at 74 million USD, equal to $85.9 \%$ of the plan and $103.5 \%$ over the same period; foreign currency revenue reached 109,6 million USD, equal to $111 \%$ of the plan and $13.7 \%$ over the same period. The period of 2012-2016 the export value as following in Table 3.

In the group of agricultural products of Thanh Hoa province, fishery product, shrimp, manioc products and vegetable \& fruit account for the largest proportion, followed by pork, reed materials with $26 \%, 18 \%, 17 \%$ and $16 \%$ respectively.

Table 1. Classification of SMEs worldwide

\begin{tabular}{|l|c|c|c|}
\hline Organization & Maximum Number of employees & Maximum value of assets (USD) & Maximum revenue (USD) \\
\hline World bank & 300 & $1,500,000$ & $3,000,000$ \\
\hline MIF - IADB & 100 & None & $15,000,000$ \\
\hline African Development Bank & 50 & (No official definition. Uses only definitions of individual national governments.) \\
\hline Asian Development Bank & 200 & None & None \\
\hline UNDP & \multicolumn{2}{|c|}{ none } \\
\hline
\end{tabular}

(Source: Author collects from the WB data, 2016).

Table 2. Category of small and medium enterprises in Viet Nam

\begin{tabular}{|c|c|c|c|c|c|}
\hline \multirow[b]{2}{*}{ Area } & \multirow{2}{*}{$\begin{array}{c}\text { Micro enterprise } \\
\begin{array}{c}\text { Total labor } \\
\text { (people) }\end{array} \\
\end{array}$} & \multicolumn{2}{|c|}{ Small enterprises } & \multicolumn{2}{|c|}{ Medium enterprises } \\
\hline & & $\begin{array}{c}\text { Total capital } \\
\text { (billion VND) }\end{array}$ & $\begin{array}{l}\text { Total labor } \\
\text { (people) }\end{array}$ & $\begin{array}{c}\text { Total capital } \\
\text { (billion VND) }\end{array}$ & $\begin{array}{l}\text { Total labor } \\
\text { (people) }\end{array}$ \\
\hline Agricultural, forest, and fishery & Under 10 & Under 20 & From 10 to 20 & From 20 to 100 & From 200 to 300 \\
\hline Industry and Construction & Under 10 & Under 20 & From 10 to 20 & From 20 to 100 & From 200 to 300 \\
\hline Services and commerce & Under 10 & Under 10 & From 10 to 50 & From 10 to 50 & From 50 to under 100 \\
\hline
\end{tabular}

(Source: According to Article 3 of Decree 56/2009 ND-CP).

Table 3. Export turnover and share by fields in the period of 2012 - 2016 (Unit: Million USD)

\begin{tabular}{|c|c|c|c|c|c|}
\hline Exporting Field & Year 2012 & Year 2013 & Year 2014 & Year 2015 & Year 2016 \\
\hline Agricultural product & 135.286 & 73.028 & 82.191 & 95.625 & 142.539 \\
\hline Industrial products & 461.471 & 695.052 & 785.835 & $1,292.545$ & $1,412.935$ \\
\hline Minerals, construction material & 50.654 & 72.644 & 88.380 & 58.481 & 54.126 \\
\hline Foreign exchange receipts & 83.265 & 85.306 & 86.470 & 102.961 & 109.589 \\
\hline Total & 730.676 & 926.030 & $1,042.876$ & $1,549.612$ & $1,719.189$ \\
\hline
\end{tabular}

Source: General statistic Organization and Department of Import-Export Management, Thanh Hoa Department of Industry and Trade, 2017.

Table 4. The value of agricultural exports of Thanh Hoa compared with the total value of agricultural exports of Vietnam (Unit: Million USD)

\begin{tabular}{|c|c|c|c|}
\hline \multirow{2}{*}{ Year } & \multicolumn{2}{|c|}{ Export value } & \multirow{2}{*}{ Thanh Hoa share in total } \\
\hline & Vietnam & Thanh Hoa & \\
\hline 2005 & 7,570 & 102 & $1.35 \%$ \\
\hline 2010 & 19,152 & 78.3 & $0.41 \%$ \\
\hline 2011 & 22,227 & 104.54 & $0.47 \%$ \\
\hline 2012 & 24,040 & 135.286 & $0.56 \%$ \\
\hline 2013 & 27,500 & 73.028 & $0.27 \%$ \\
\hline 2014 & 30,540 & 82.191 & $0.28 \%$ \\
\hline 2015 & 30,140 & 95.625 & $0.32 \%$ \\
\hline 2016 & 32,400 & 142.359 & $0.44 \%$ \\
\hline
\end{tabular}

Source: General statistic Organization and Department of Import-Export Management, Thanh Hoa Department of Industry and Trade, 2017. 
The summarized results show that the value of agricultural export of Thanh Hoa is minimal compared to Vietnam's total export turnover with only $0.3-1.35 \%$. Besides, the share of agricultural export turnover tends to decrease compared to the total export turnover of the province for the last three years. This proves that the agricultural export capacity of local enterprises is limited and need adjusting accordingly. Regarding agriculture sector, the agricultural export value accounts for only $6-10 \%$ of the total production value of the province. This rate is meager compared to that of industry and mineral sectors. There are many reasons for this limitation such as weak linkages in the formation of product value chain, limited production materials and land for agricultural cultivation; incomplete farmers' awareness and cultivation towards sustainability and safety, resulting in an insufficient quantity of agricultural products for export. Another critical factor is the difficulty in finding export markets because of SMEs lack capital and capacity and experience weaknesses in approaching the international market.

\section{Review the Related Literature to Research}

To date, there are a lot of scientific researches about the factors affecting the business success of the firm in general and exporting firms in particular. Therefore, abundant of related literature was built. There are a considerable amount of factors that can be affecting the performance of firms in different ways. In this research uses critical success factors (CSF) and five success factors of E. W "Bruck" Lawrimore as support literature to study.

- Internal factors

Internal factors are the group of inside effecting directly on business performance such as manager's competency, human resource, business culture, capital result, business strategy, product and service, vision and mission, business know-how. In this research, six internal factors are chosen to measure their effect on the business success of agricultural exporting firms as follows:

Manager's capacity: Characteristics of manager play a vital role in the export success of SMEs. When analyzing the export performance of the firm, one must consider another component of the management is the decision maker [8]. Laguna et al. [9] showed that general and particular managerial skills are significant predictors of success in running a business. Specific managerial competencies proved to be a mediator between general competencies and SME success.

Capital resource: Lack of financing is considered a significant challenge to the growth of SMEs, and it has accounted for high rates of failure among those SMEs. According to Shah et al. [10], the export success of SME come from its source and capital. In a study in Australia, McMahon [11] discovered that greater dependence upon external finance associated with better business growth. In a more recent study, in Indonesia, Kristiansen, Furuholt, $\&$ Wahid [12] found that financial flexibility significantly correlates to business success.

Human resource: Human resources capacities form one of the most significant factors for the development of
SMEs [13]. Chandler and McEvoy [14], indicate that human resource capacities have a positive effect on the growth of small firms, which increase employee skills and motivation and eventually result in improving the productivity and long-term sustainability of small firms. The research about export success factors of SMEs in Chile state that, the human resource has actively effecting exporting SME's business success [15]. According to Aaby and Slater [16] export performance is determined by human resource and technological capabilities of firms. Loan [17] showed that government support policy, market, infrastructure, human resource are the main factors affecting agri based exporting SME's development and performance. Elahe Kinai Harchegani [18] points out that human resource has a significant relationship with business success of exporting firm.

Business strategy: Business strategy and marketing strategy can define as the mean by which a firm responds to the interplay of internal and external forces to meet the objectives of export performance [19]. In the research of Julian C. and Aron O'Cass [20] find out that export strategy is the critical determining factor affecting marketing strategy and the decision factors adapt to the conditions of the foreign market.

Linkage: The business linkage has an impact on the likelihood of successful entrepreneurial endeavor. The study of entrepreneurship has increasingly reflected the general agreement that entrepreneurs and new companies must engage in networks to survive [21]. Base on the review of Nurul Indarti [22], the business linkage represents a means for entrepreneurs to reduce risks and transaction costs and also to improve access to business ideas, knowledge and capital [23]. The business linkage consists of a series of formal and informal ties between the central and other actors in a circle of acquaintances and represents channels through which entrepreneurs get access to the necessary resources for business start-up, growth, and success [24]. [25] found that exporting SMEs have business linkages definition perform better than those who do not. The research of Nazrul Islam \& Mukit [26] points out that business network has positively affected the business success of the firm.

Product and service: Product and service is factor decides the success of import-export enterprises [27]. According to Leonidoua et al. [28], studying the relationship between export marketing strategies and export performance showed that, the product design, style, and branding have a significant positive effect on export performance. Similarly, the pricing strategy, product deference are positively associated with export performance too [29]

\section{- External factors}

External factors including outside indicators which have a substantial impact but out of firm's control [26].

Market and customer: Market and customer refer to the size of the market, the physical distance, and demand. So the selection the match with the exporting firm in term of demand, feature, potential can consider as critical factors for business success because these market need a little money for internal marketing and another cost [17].

Government support and Political: According to Nazrul Islam \& Dewan Muktadir - Al Mukit [26] Philip [30], 
Chittithaworn [31] stated that government support (political and policy) is a critical factor for the business success of exporting firms. [17] showed that government support policy, market, infrastructure, human resource are the main factors affecting agri based exporting firm's development and performance.

Natural resource: is one of the basic elements of the business life [32]. This is one of the essential factors affecting agriculture file thus directly cause agri based exporting firms. A country with favorable natural conditions will help to develop the agricultural production, thus facilitating other developmental areas such as agricultural exports, processing, and tourism as well [27]

Technology: The development of science and technology creates the best conditions for the production, purchase, and preservation of agricultural products, thereby increasing the value and efficiency of the business. Besides that, the development of information technology helps businesses to be more active in the global connection through e-commerce, fan page, website [17]. However, technology is also a challenge for exporters of agricultural products because most of them are small in size and limited in the capital, so they cannot invest in technology equipment for storage [33]. According to Justus \& Daniel [34], the survival and growth of firms depend on the continued and expanded use of the technology vintage that was new at the time when the firm was created. Enterprises with modern technology have advantages over other firms in the same field [7]. Information technology is a necessary complementary factor for the operation of enterprises, especially enterprises operating in the international environment. Good information technology provides a solid foundation for the implementation of corporate governance [33].

- Measure the business success of exporting firm

Although several measures have advocated for conceptualization and operationalization of export performance, there is not a consensus on this point. The measures of export success are grouped into two categories representing financial and non-financial indicators. Financial indicators include sales, profit, and growth rate [26] Moreover, nonfinancial including customer's satisfaction, employee's growth, goal achievement, new markets, increasing the number of export markets and export products, gaining advantages over competitors, responding to domestic competitive pressure and gaining the prestige [35].

From the review of literature and studies, regarding factors influencing the business success of Agri based exporting firms, each research focused on specific factors. Most of them examined the factors in the context of developing countries, therefore, in general, this is suitable for the research finding. In the context of this research, we based on the finding of a study in the same field of Thailand, Indonesia, Bangladesh, countries have the same economic and resource condition to Vietnam while taken suggestions from the qualitative study into account. There are ten factors were selected, including Manager's capability, Human resources, Products, Capital resource, Business strategy, Linkage, Market, and customers, Political and government support, Natural resource and Technology strongly affecting export performance, from that determine the business success of Agri based exporting firms.

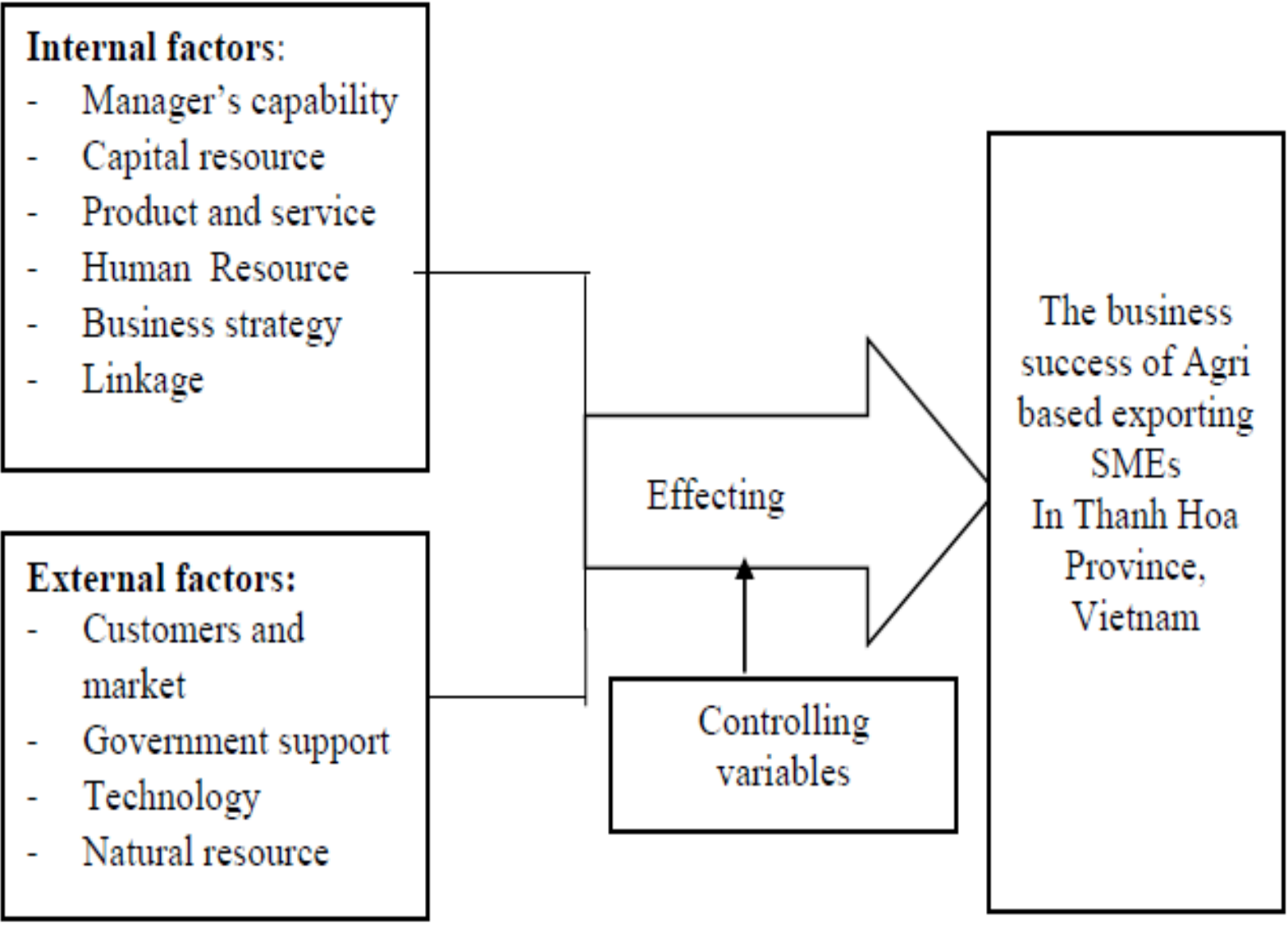

Figure 1. The research mode 


\section{Research Model}

To get the research goal set out, the study utilized both quantitative and qualitative approach of research combined with the descriptive method which depicts the state of affairs as it exists at present. The optimal sample size is chosen to depend on the expectation of reliability, the method of data analysis, the estimation method used in the study, the parameters to be estimated. To conduct the best regression analysis, according to Tabachnick and Fidell [36] the sample size $\mathrm{n} \geq 8 \mathrm{~m}+50$ ( $\mathrm{m}$ is the independent variable in the model); Also according to Aprimer $\mathrm{n} \geq 104+\mathrm{m}$. According to Slovin's formula, the number of observations in the sample can estimate as following formula: $\mathrm{S}=\frac{N}{\left(1+N e^{2}\right)}$ (Where: $\mathrm{N}$ the population, e: Error). To test the scale, the researchers did not give a specific figure on the sample size needed but gave the ratio between the required sample size and the number of parameters to be estimated. For factor analysis, the sample size will depend on the number of variables included in the factor analysis. Hair [37] suggests that the sample size is five times the number of variables [37]. Meanwhile, Hoang Trong [38] stated out that sample size needs four or five times the number of variables. There are 11 variables and 49 observation variable in this research. Base on Slovin's formula, Hair, Hoang Trong, and Tabachnick sample method total observations are must bigger than 150 with error 5\%. To meet the targeted research 275 questionnaires were taken as respondents, but only 192 answer sheets were responded and collected and only 180 respondents are suitable for research analysis.

\section{Result and Discussion}

\section{- Descriptive statistics}

The age of the administrators in the enterprise of 35 or more accounts for over $70 \%$ of which the number of people aged $40-60$ accounts for over $40 \%$. $73 \%$ of executives are male, $27 \%$ are female, this is in line with the gender ratios of provincial and national directors. Regarding qualifications, $100 \%$ graduated from high school, $70 \%$ graduated from university, $30 \%$ had master's degree, but only $23 \%$ graduated from economics, management, and business. Business governance experience is relatively low, with only $22.6 \%$ having $10-15$ years of experience and almost $24 \%$ having more than 15 years of management experience. Of which, those having over ten years of experience in import-export activities account for only $16 \%$; The managers having more than ten years of experience enjoy a higher success rate than those having less than ten years (see Table 5).

Most of the small and medium enterprises (over 90\%), the number of enterprises with turnover over 500 billion VND accounts for nearly $20 \%$. The agri-based exporting enterprises in Thanh Hoa have not established for a long time; the number of enterprises established under nine years accounts for nearly $80 \%$ of the total; $92 \%$ were private enterprises, $63 \%$ operated as joint stock companies. For essential export items, vegetables, sedge, fish, shrimp, cassava and meat, the meat account for the most significant share by nearly $70 \%$, followed by sugarcane, rice, and other agricultural products. Currently, China, Korea, Taiwan, USA, India are the most significant export partners of Thanh Hoa in general and agri-products in particular with a market share of $53 \%$. Concerning sales, agri-products ranked second in export product categories with a value of $\$ 142.539$ million in 2016, equivalent to $10 \%$ of the province's export value and $1.3 \%$ of the total export turnover. Over the past years, the export turnover of agri-products tends to go up steadily with the increase rate from $8 \%-15 \%$ per year.

\section{- Research discussion}

Cronbach's Alpha analysis: The reliability of the scale is evaluated by the internal consistency method using the Cronbach's Alpha coefficient. The Cronbach's Alpha coefficient of reliability method used before analyzing the exploratory to reject unsuitable variables as these junk variables can create false factors [39]. To find the results of the study, we conducted Cronbach's Alpha analysis on each scale and observed variables.

Table 5. Frequency and Percentage Distribution of Respondents to demographic

\begin{tabular}{|c|c|c|c|c|c|}
\hline Items & Frequency & Percentage & Items & Frequency & Percentage \\
\hline Gender & & & Graduate & & \\
\hline Male & 125 & $69.4 \%$ & Graduate & 25 & $13.89 \%$ \\
\hline Female & 55 & $30.6 \%$ & Under graduate & 137 & $76.11 \%$ \\
\hline Age & & & Master & 18 & $10.00 \%$ \\
\hline under 20 & 3 & $1.67 \%$ & $\mathrm{PhD}$ & 0 & $0.00 \%$ \\
\hline From $20-<34$ & 50 & $27.78 \%$ & Year of experience & & \\
\hline From $35-<44$ & 70 & $38.89 \%$ & Under 5 year & 59 & $32.78 \%$ \\
\hline From 45-60 & 51 & $28.33 \%$ & $5-9$ years & 76 & $42.22 \%$ \\
\hline \multirow[t]{2}{*}{ Over 60} & 6 & $3.33 \%$ & $10-15$ year & 33 & $18.33 \%$ \\
\hline & & & Over 15 years & 12 & $6.67 \%$ \\
\hline
\end{tabular}


Table 6. Frequency and Percentage Distribution of Respondents to firms

\begin{tabular}{|c|c|c|c|c|c|}
\hline Items & Frequency & Percentage & Items & Frequency & Percentage \\
\hline Number of employer & & & Revenue & & \\
\hline Under 10 & 45 & $25.00 \%$ & Under 10 Billion VND & 12 & $6.67 \%$ \\
\hline $10-49$ & 97 & $53.89 \%$ & $10-50$ & 35 & $19.44 \%$ \\
\hline $50-99$ & 32 & $24.00 \%$ & $50-100$ & 65 & $36.11 \%$ \\
\hline $100-200$ & 6 & $7.00 \%$ & $100-500$ & 33 & $18.33 \%$ \\
\hline over 200 & 0 & $0.00 \%$ & Over 500 Billion VND & 35 & $19.44 \%$ \\
\hline Capital resource & & & Year of experience & & \\
\hline Under 10 Billion VND & 44 & $24.44 \%$ & Under 5 years & 65 & $36.11 \%$ \\
\hline $10-50$ & 103 & $57.22 \%$ & $5-9$ years & 81 & $45.00 \%$ \\
\hline $50-100$ & 22 & $12.22 \%$ & $10-15$ year & 25 & $13.89 \%$ \\
\hline Over 500 & 11 & $6.11 \%$ & over 15 years & 9 & $5.00 \%$ \\
\hline
\end{tabular}

Table 7. Cronbach's Alpha analysis (first time)

\begin{tabular}{|c|c|c|}
\hline Variables & Number of observation & Cronbach's Alpha \\
\hline Manager's capability & 5 & 781 \\
\hline Capital resource & 3 & .912 \\
\hline Product and service & 4 & .909 \\
\hline Human Resource & 5 & .848 \\
\hline Business strategy & 5 & .888 \\
\hline Linkage & 5 & .778 \\
\hline Natural resource & 4 & .325 \\
\hline Customers and market & 3 & .865 \\
\hline Government support & 5 & .917 \\
\hline Technology & 3 & .404 \\
\hline Finance indicators (FI) & 3 & .860 \\
\hline Non -finance indicators (NFI) & 4 & .815 \\
\hline Total observation variables & 49 & \\
\hline
\end{tabular}

Cronbach's alpha analysing show that, two variables are rejected out research model such Natural resource (.325) and Technology (.404) due to Cronbach's Alpha $<0.5$. There are three (3) observation independent variables and one (1) observation dependent variables were rejected out of research model due to Corrected Item-Total Correlation $<0.3$ such as MC3 - manager's educational/training level is high, HR4 - employee's loyalty skill is higher as export performance is higher, LK5 - joining associations improves export success, NFI3 - The market share is increasing in three recently years. After doing Cronbach's alpha, there are 32 independent observation variables with grouped in 8 independent variables in research model. The summary of Cronbach's alpha result as following:

Table 8. Cronbach's Alpha analysis (second time)

\begin{tabular}{|c|c|c|c|c|}
\hline Code & $\begin{array}{c}\text { Scale Mean if Item } \\
\text { Deleted }\end{array}$ & $\begin{array}{c}\text { Scale Variance if Item } \\
\text { Deleted }\end{array}$ & $\begin{array}{c}\text { Corrected Item-Total } \\
\text { Correlation }\end{array}$ & $\begin{array}{c}\text { Cronbach's Alpha if } \\
\text { Item Deleted }\end{array}$ \\
\hline MC- Manager's capacity & \multicolumn{4}{|c|}{ Cronbach's Alpha = .834 } \\
\hline $\mathrm{MC1}$ & 11.26 & 5.208 & .752 & .748 \\
\hline $\mathrm{MC} 2$ & 11.10 & 5.901 & .605 & .816 \\
\hline $\mathrm{MC} 4$ & 11.29 & 5.067 & .823 & .714 \\
\hline MC5 & 11.16 & 6.657 & .492 & .859 \\
\hline CR (Capital resource) & \multicolumn{4}{|c|}{ Cronbach's Alpha = .912} \\
\hline CR1 & 7.14 & 2.918 & .854 & .851 \\
\hline $\mathrm{CR} 2$ & 7.24 & 3.166 & .861 & .842 \\
\hline CR3 & 7.23 & 3.685 & .769 & .919 \\
\hline PS (product and service) & \multicolumn{4}{|c|}{ Cronbach's Alpha = .909 } \\
\hline PS1 & 11.18 & 5.622 & .809 & .876 \\
\hline PS2 & 11.18 & 5.398 & .837 & .866 \\
\hline PS3 & 11.03 & 6.005 & .762 & .893 \\
\hline PS4 & 11.02 & 5.782 & .767 & .891 \\
\hline
\end{tabular}




\begin{tabular}{|c|c|c|c|c|}
\hline Code & $\begin{array}{c}\text { Scale Mean if Item } \\
\text { Deleted }\end{array}$ & $\begin{array}{c}\text { Scale Variance if Item } \\
\text { Deleted }\end{array}$ & $\begin{array}{c}\text { Corrected Item-Total } \\
\text { Correlation }\end{array}$ & $\begin{array}{c}\text { Cronbach's Alpha if } \\
\text { Item Deleted }\end{array}$ \\
\hline HR (Human resource) & \multicolumn{4}{|c|}{ Cronbach's Alpha $=.848$} \\
\hline HR1 & 10.68 & 7.616 & .722 & .920 \\
\hline HR2 & 10.83 & 7.089 & .815 & .888 \\
\hline HR3 & 10.72 & 7.408 & .836 & .881 \\
\hline HR5 & 10.72 & 7.366 & .861 & .872 \\
\hline BS (Business strategy) & \multicolumn{4}{|c|}{ Cronbach's Alpha $=.888$} \\
\hline BS1 & 14.16 & 10.337 & .716 & .866 \\
\hline BS2 & 14.29 & 10.899 & .638 & .883 \\
\hline BS3 & 14.17 & 9.950 & .845 & .836 \\
\hline BS4 & 14.19 & 10.668 & .657 & .880 \\
\hline BS5 & 14.28 & 10.338 & .793 & .849 \\
\hline LK (linkage) & \multicolumn{4}{|c|}{ Cronbach's Alpha $=.778$} \\
\hline LK1 & 10.95 & 5.925 & .498 & .837 \\
\hline LK2 & 10.93 & 4.934 & .727 & .740 \\
\hline LK3 & 10.99 & 4.547 & .751 & .725 \\
\hline LK4 & 10.93 & 4.872 & .626 & .788 \\
\hline CM (Customer and market) & \multicolumn{4}{|c|}{ Cronbach's Alpha $=.865$} \\
\hline CM1 & 7.01 & 3.218 & .776 & .780 \\
\hline $\mathrm{CM} 2$ & 7.22 & 3.701 & .691 & .857 \\
\hline CM3 & 7.13 & 3.475 & .768 & .789 \\
\hline GS (Government support) & \multicolumn{4}{|c|}{ Cronbach's Alpha $=.917$} \\
\hline GS1 & 15.31 & 10.785 & .824 & .891 \\
\hline GS2 & 15.33 & 10.570 & .809 & .895 \\
\hline GS3 & 15.25 & 11.105 & .824 & .891 \\
\hline GS4 & 15.26 & 11.255 & .790 & .898 \\
\hline GS5 & 15.18 & 12.225 & .696 & .916 \\
\hline
\end{tabular}

All independent variables have a high Alpha Coefficient above 0.6, and Corrected Item-Total Correlation was higher than 0.3. This also demonstrates that the observed variables in the affecting factors determining the business success of exporting firms have a very strong correlation in the research model and guarantee the inclusion of the EFA factor analysis.

Exploratory Factor Analysis (EFA): Maximum factor loading coefficient for each scale system $>0.5$, total Average Variance Extracted (AVE) $>50 \%$, KMO coefficient $>0.5$, and Bartlett's test of statistically significance.

\section{KMO and Bartlett's Test}

\begin{tabular}{|l|l|l|}
\hline Kaiser-Meyer-Olkin Measure of Sampling Adequacy. & .837 \\
\hline \multirow{3}{*}{ Bartlett's Test of Sphericity } & Approx. Chi-Square & 4080.494 \\
\cline { 2 - 3 } & df & 496 \\
\cline { 2 - 3 } & Sig. & .000 \\
\hline
\end{tabular}

Rotated Component Matrix
The result of EFA analysis shows that the total deviation is $61.3 \%(>50 \%)$ and $\mathrm{KMO}$ is $0.837(>0,5)$, and Bartlett is statistically significant (Sig. <.05), so EFA analysis is appropriate. The model is not different from the study model, and only a few observable variables were not reliable enough to be excluded from the study variable. Therefore, there are 8 group of factors be formed in the model and do not new factors created.

Regression analysis: Regression testing shows that Sig. $=0.000$, Adjusted R Square $=.631$ This demonstrates the suitability of the research model, which means that over $50 \%$ of the business success of agri based exporting firm is explained by the eight proposed research variables in the model. The Durbin-Watson coefficient $=1.430$ $(>1)$ indicates that there is no autocorrelation between variables. The results of multiple regression analysis are as follows:

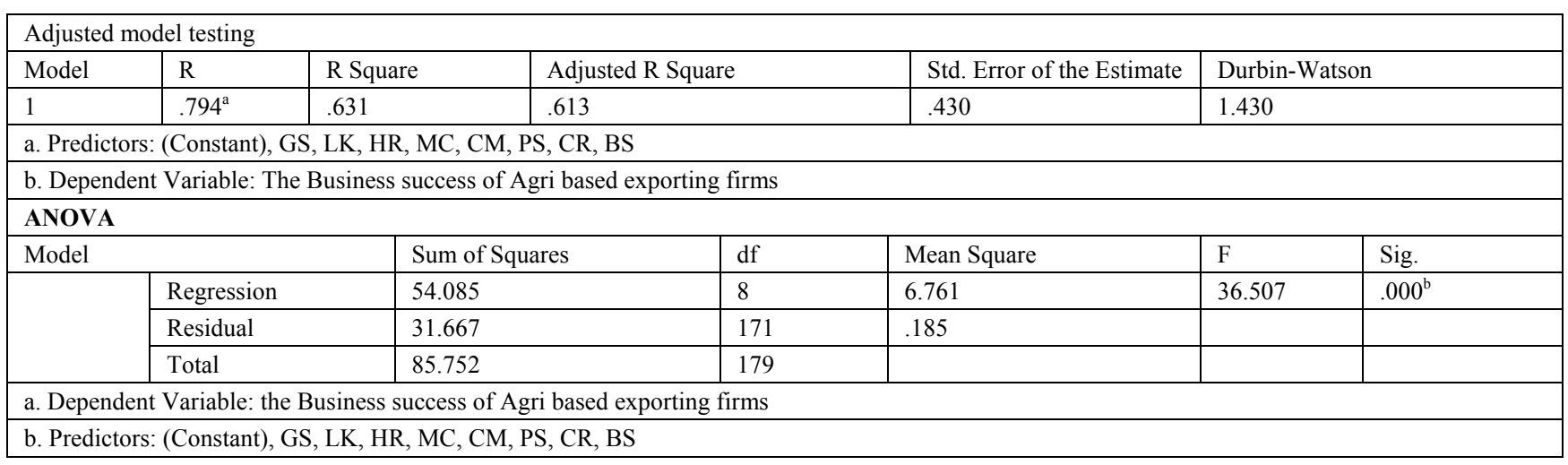


Table 9. Result of Multiple regression analysis

\begin{tabular}{|c|c|c|c|c|c|c|c|}
\hline \multicolumn{9}{|c|}{ Multiple regression analysis } \\
\hline
\end{tabular}

Dependent Variable: Business success of Agri based exporting firms

Thus, according to the equation of all eight selected factors are important to influence the success of agricultural exporters. The regression equation as follows:

$$
\begin{aligned}
& \text { SMEs }=0.145 \mathrm{MC}+0.190 \mathrm{CR}+0.153 \mathrm{PS}+0.161 \mathrm{HR} \\
& +0.129 \mathrm{BS}+0.189 \mathrm{CM}+\mathbf{0 . 1 6 0 L K}+\mathbf{0 . 1 8 5 G S} .
\end{aligned}
$$

The importance of each factor depends on the standardized Beta (regarding the absolute value of the coefficient), or the factor with a larger standardized Beta has a stronger impact on the business success of the enterprise. Specifically, capital resource, customer and markets and government support policy have the strongest impact on the success of agricultural exporters.

\section{Conclusion}

To achieve the objectives of the thesis, quantitative and qualitative research methods were used concurrently where the qualitative method was conducted first to analyze secondary materials, to develop model, scale before carrying out quantitative research. There were ten factors proposed to have a decisive impact on the business success of agri based exporting SMEs. The 275 questionnaire was sent out, 180 questionnaires were collected, aggregated and cleaned before being included in the quantitative analysis. The research results show that eight proposed factors have a significant relationship to business success, in which external factors have much effect than some internal one. In specific, customer and market, government support, capital resource, human resources have the most substantial effect, following by leadership capability, business linkage, business strategy, product, and service. This result means that external factors have much effect the Business Success of Agri-based Exporting Small and Medium-Sized Enterprises in Thanh Hoa Province than internal factors.

\section{References}

[1] Amornkitvikai et al., A. Y. (2012). Factors affecting the export participation and performance of manufacturing small and Medium-sized Enterprises (SMEs). 57th International Council for Small Business World Conference. Wellington, New Zealand: International Council for Small Business.
[2] GSO. (2016). The socio-economic situation in Vietnam for 5 years. General Statistic Office of Vietnam.

https://www.gso.gov.vn/Default.aspx?tabid=217.

[3] Vietnames Custom. (2016). Annual report about contributes of exporting sectors. Vietnamese Custom, https://www.customs.gov.vn/default.aspx

[4] Phan, T. M. (2011). Factors affecting the SMEs performance in Thua Thien Hue Province, Vietnam. Journal of science and technology, 43(2), 151-157.

[5] Krishna Moorthy, A. T. (2012). International Journal of Academic Research in Business and Social Sciences. 2(4).

[6] Loc, V. T. (2016). SMEs annual 2016. VCCI, Vietnam Charm of Commerce and Industry.

[7] VCCI, V. C. (2016). Vietnam annual report 2016, Company Management. Information and communication Publishing House.

[8] Amstrong, M. (2007). A Handbook of Human Resource Management Practice.

[9] Luguna. M, W. T. (2012, December). The competencies of managers and their business success. Central European Business Review, 1(3), 7-13.

[10] Shah, S., Nazir, T., Zaman, K. and Shabir, M. (2013). Factors Affecting the Growth of Enterprises: A Survey of the Literature from the Perspective of Small- and Medium-Sized Enterprises. Journal of Enterprise Transformation, 3(2), pp.53-75.

[11] McMahon, R. G. P. (2001). Growth and performance of manufacturing SMEs: The influence of financial management characteristics. International Small Business Journal, 19(3), 10-28

[12] Kristiansen. (2003). Social network and business success. The International Journal of entrepreneurship and innovation.

[13] Lee, C. (2001). "Internal capabilities, external networks, and Performance: A study on technology- based ventures". Strategic Management Journal, 22: 615-640.

[14] Chandler G.N \& McEvoy, G.M (2000). Human resource management, total quality management and firm performance in small and medium-sized enterprises. Entrepreneurship theory and practice 25 (1) $43-57$

[15] O Maldifassi Jose' at el, C. (2014). Export success factors of SMEs in Chile. Journal of Small business and Enterprise Development, 21(3), 450-569.

[16] Aaby, N. E., and Slater, S. F. (1989), "Management Influences on Export Performance: A Review of the Empirical Literature 197888", International Marketing Review, vol. 6, no. 4, pp. 7-25.

[17] Loan, N. T. (2015). Factor affecting the business success of agriculture SMEs in Vietnam. Science journal of Hong Duc University, 21(1), 76-98.

[18] Elahe Kinai Harchegani \& Abolfazl Solati, P. F. (2015). identifying the factors affecting SME's export performance (case study: sports equipment's exporters). Engineering, Management an Technology, 3(3), 390-400.

[19] Cavusgil S and Zou, S. (1994). Marketing Strategy-Performance Relationship: An Investigation of the Empirical Link in Export Market Ventures. Journal of Marketing, 58, 1-21.

[20] Julian, CC \& O'Cass, 2004, 'The antecedents of export marketing performance: an Australian perspective', Journal of Asia Pacific 
Marketing: Special Issue on Export Marketing in the Asia Pacific Region, vol. 3, no. 2, pp. 99-113.

[21] Huggins, R. (2000). The success and failure of policy-implanted inter-firm network initiatives: motivations, processes, and structure. Entrepreneurship and Regional Development, 12(2), p.211-236.

[22] Nurul Indarti \& Marja Langenberg, M. (2004). Factors affecting business success among SMEs: Empirical evidence from Indonesia. Proceeding of second Biannual European summer University. University of Twente, Enschede, The Netherlands.

[23] Aldrich, H. \& Zimmer, C. (1986). Entrepreneurship through social networks. In D.L. Sexton and R.W. Smiler, eds. The Art and Science of Entrepreneurship. Cambridge, MA: Ballinger, p. 3-23

[24] Kristiansen, S. (2003). Linkages and Rural Non-Farm Employment Creation: Changing Challenges and Policies in Indonesia. Rome.

[25] Gumede, V \& Rasmussen, VK. (20020 "Small manufacturing enterprises and exporting in South Africa: a preliminary assessment of key export success factors." Journal of Small Business and Enterprise Development, 9 (2) P.162-171.

[26] Nazrul Islam Dr. (kurtulus.yilmaz.genc, 2013)\& Dewan Muktadir - Al Mukit, L. (2014). Factors Determining the Success of SMEs in Bangladesh.

[27] My, N. T. (2016). Factors affecting agro-export performance of Vietnam. Thai Nguyen University, Vietnam, P.52-121

[28] Leonidoua, K. S. (2002). Marketing strategy determinants of export performance: a meta-analysis. Journal of Business Research, 55(5), 51-67.

[29] Tuba Yakici Ayan, a. S. (2005). A Structural Analysis of the Determinants of Export Performance: Evidence from Turkey. innovative Marketing, 1(2), 106-120.
[30] Philip \& Mathew. (2010, 11). APJRBM Volume 1, Issue 2 (November 2010) ISSN 2229-4104 Sri Krishna Internatio. APJRBM Volume 1(2).

[31] Chittithaworn, C. I. (2011). Factors Affecting Business Success of Small and Medium Enterprise (SMEs) in Thailand. Asian Social Science, 7(5), 180-190.

[32] Kurtulus.yilmaz.genc. (2013). Natural environment as a strategic issue for firms: theoretical perspectives. Procedia - Social and Behavioral Sciences 99, 143-153.

[33] Thanh N. K. (2013). Student book: Business management (Vol. 3). Ha Noi: National Economic University .

[34] Justus B. \& Daniel f. (2017). The Effect of Technological Change on Firm Survival and Growth - Evidence from Technology Standards. Retrieved from https://pdfs.semanticscholar.org/7cd7/7c82da3a696dcf7e7e6ba9e6 a7fc3e40d6c5.pdf.

[35] Kotane, I. (2015). Evaluating the importance of financial and nonfinancial indicators for the evaluation of company's performance. Management Theory and Studies for Rural Business and Infrastructure Development, 37(1), 80-94.

[36] Tabachnick, B. G., \& Fidell, L. S. (1996). Using multivariate statistics (3rd ed.). New York: HarperCollins.

[37] Hair JF., B. W. (2006). Multivariate Data Analysis, (6 ed.). Upper Saddle River NJ, Prentice Hall.

[38] Hoang Trong, Ngoc C. N. M (2008). Data analysis in business. Hong Duc, Ha Noi Vietnam.

[39] Nguyen Dinh Tho. (2011). Research methodology in economic, design and practics. Labour Publisher. Ha Noi, Vietnam. 